\title{
Effects of Priming Techniques on Seed Germination and Early Growth Characteristics of Bromus tomentellus L. and Bromus inermis L.
}

\author{
Ali TAVILI' ${ }^{1)}$, Salman ZARE ${ }^{11}$, Seyed Amir MOOSAVI'2), Abdolghader ENAYATI ${ }^{2)}$ \\ 1) University of Tehran, Faculty of Natural Resource,Iran; atavili@ut.ac.ir; zaresalman@yahoo.com \\ 2) University of Tehran, Faculty of Agriculture, Iran; amir.msa@gmail.com; enayati1359@gmail.com
}

\begin{abstract}
Seed priming is known as a seed treatment which improves seed performance under environmental conditions. Objective of this study was to evaluate the effects of different priming treatments on seed germination behaviour of two genotypes of Bromus under laboratory conditions to find out the most effective priming treatment. Seeds were treated with the following seed-soaking media: (i) unsoaked seed (control); (ii) hydropriming with distilled water for 4, 8, 12 and 16 hours, (iii) osmopriming treatments with PEG 6000 for Bromus tomentellus were - $-0.6,-0.8,-1.0$ and $-1.2 \mathrm{MPa}$ osmotic potentials with duration of 12, 24 and 36 hours and for Bromus inermis osmoticpotentials were the same as B. tomentellus but duration of priming treatments was soaking seeds for 12, 24, 36 and 48 hours. Seeds of both genotypes were placed in liquid priming media at $25^{\circ} \mathrm{C}$. Priming treatments significantly affected germination vigour of both genotypes. The response of both genotypes to different priming techniques approximately was similar. Osmopriming treatment $(-0.6 \mathrm{MPa}$ and $12 \mathrm{~h})$ increased final germination percentage of $B$. tomentellus. Priming treatments increased coleoptile length significantly comparing to control but hydropriming for $4 \mathrm{~h}$ exhibited longer coleoptile than others. Higher vigour index was observed in hydropriming for $12 \mathrm{~h}$ but this difference was not significant with osmoprime treatment (12 h-0.6 Mpa). B. inermis produced more germinated seeds and vigourous seedlings than B. tomentellus but germination rate was higher in B. tomentellus.
\end{abstract}

Keywords: Bromus inermis, Bromus tomentellus, germination, priming

\section{Introduction}

Seed priming is known as seed treatment wich improves seed performance under environmental conditions. In fact seed priming is a procedure that partially hydrates the seed, then seeds are dried, so that germination processes begin, but radicle emergence does not occur. Methods of seed priming have been described comprehensively by Bradford (1986) and Khan (1992) which include soaking seed in water or osmotic solution, and intermixture with porous matrix material.

Lots of information are available which show hydration of seeds up to, but not exceeding, the lag phase with priming increased RNA and protein synthesis ( $\mathrm{Fu}$ et al., 1988, faster embryo growth (Dahal et al., 1990) and reduced leakage of metabolites (Styer and Cantliffe, 1983) compared with control. Seed priming has been found a doable technology to enhance rapid and uniform emergence, high vigour, and better yields in vegetable and flower species (Dearman et al., 1987; Parera and Cantliffe 1994; Bruggink et al., 1999), small seeded grasses (Heydecker and Coolbaer, 1978; Bradford, 1986) and some field crops (Hartz and Caprile, 1995; Chiu et al., 2002; Giri and Schillinger, 2003; Murungu et al., 2004; Basra et al., 2005, 2006; Kaur et al., 2005; Kaya et al., 2006; Farooq et al., 2006 a, b; 2007 a, b; Janmohammadi et al., 2009).

Seed priming is commonly used to reduce the time between seed sowing and seedling emergence (Parera and Cantliffe, 1994). Earlier works showed that the success of seed priming is influenced by the complex interaction of factors including plant species, water potentiality of the priming agent, duration of priming, temperature, seed vigour and dehydration, and storage conditions of the primed seed (Parera and Cantliffe, 1994). Although, the previous studies indicate that some benefits are associated with pre-sowing treatments for seed vigour enhancement, but there is dearth of information about the germination performance of primed seeds of Bromus spp. Therefore, the present study was carried out with the objective of evaluating the effects of different priming treatments on seed germination behaviour of two genotypes of Bromus under laboratory conditions to find out the most effective priming treatment.

\section{Materials and methods}

The study was conducted in the seed laboratory of Natural Resources Faculty, University of Tehran, Iran. Seeds of two Bromus genotypes including B. tomentellus and 
$B$. inermis subjected to seed priming. Seeds were treated with the following seed-soaking media: (i) unsoaked seed (control); (ii) hydropriming with distilled water for 4, 8 , 12 and 16 hour; (iii) osmopriming treatments with PEG 6000 for $B$. tomentellus were $-0.6,-0.8,-1.0$ and $-1.2 \mathrm{MPa}$ osmotic potentials with duration of 12, 24 and 36 hours while for $B$. inermis osmotic potentials were the same as $B$. tomentellus but duration of priming treatments was soaking seeds for 12, 24, 36 and 48 hours. Seeds of both genotypes were placed in liquid priming media at $25^{\circ} \mathrm{C}$. Seeds were covered with plastic bags to refuse moisture loss.

After soaking, seeds were washed with distilled water, then redried in the incubator at $25^{\circ} \mathrm{C}$ in the dark. Germinaton test was conducted by placing 25 seeds from each of the treatments in $90 \mathrm{~mm}$ diameter Petri dishes on Whatman filter paper that was moistened with $5 \mathrm{ml}$ distilled water. Seeds were kept in germinator at $25^{\circ} \mathrm{C}$ in dark condition. A completely randomized design with three replications was used. Radicle protrusion of $2 \mathrm{~mm}$ was scored as germination (Kaya et al., 2006). Germination was counted in 24 hours intervals and continued until no further germination occurred. The seedlings were evaluated as described in Seedling Evaluation Handbook (AOSA, 1991).

Final germination percentage (\%), coleoptile and radicle length $(\mathrm{cm})$ and seedling length $(\mathrm{cm})$ was recorded after 14 days of planting on filter paper. For statistical analysis, the data of germinating percentage was transformed to $\arcsin \sqrt{ }(100 / X)$. Experimental data was analyzed by a statistical packet SAS, version 6.12. Treatments means were compared using Duncan's multiple comparsion test at $5 \%$ level of probability. The vigour index was calculated according to the following formula:

Vigour index $(\mathrm{VI})=[$ seedling length $(\mathrm{cm}) \times$ germination percentage]

Mean germination time (MGT) was calculated based on the Ellis and Roberts equation (1981).

\section{Results}

Priming treatments significantly affected germination vigour of both genotypes. The response of both genotypes to different priming techniques approximately was similar. Speed of germination was recorded for hydro and osmoprimed seeds as indicated by lower value of MGT or by higher germination rate (Tab. 1 and 2$)$.

Osmopriming treatment (-0.6 Mpa and $12 \mathrm{~h}$ ) increased final germination percentage of $B$. tomentellus by $22 \%$ while hydropriming $(4 \mathrm{~h})$ increased germination percentage about $12 \%$ compared to control. So, B. tomentollus germination percentage exhibited posetive response to osmopriming than hydroprimig (Tab. 1). But for germination rate, osmopriming treatment could not exhibit significant effect while hydropriming treatment ( 4 and $8 \mathrm{~h}$ ) had significant effect and hydroprimed seed for $4 \mathrm{~h}$ germiated faster than non-primed treatment. All priming treatments increased coleoptile length significantly compared to control but hydropriming for $4 \mathrm{~h}$ exhibited longer coleoptile than the others.

Radicle length of osmoprimed seeds increased due to priming treatment of (-0.6 Mpa, $12 \mathrm{~h})$ significantly while hydropriming showed no significant result. All priming treatments increased seedling length of $B$. tomentellus

Tab. 1. Effect of priming treatments on the germination and seedling characteristics of Bromus tomentellus

\begin{tabular}{|c|c|c|c|c|c|c|c|c|c|}
\hline \multicolumn{3}{|c|}{ Treatments } & $\begin{array}{c}\text { Final } \\
\text { germination (\%) }\end{array}$ & $\begin{array}{c}\text { Germination } \\
\text { rate }\end{array}$ & $\begin{array}{l}\text { MGT }^{1} \\
\text { (day) }\end{array}$ & $\begin{array}{l}\text { Coleoptile } \\
\text { length }(\mathrm{cm})\end{array}$ & $\begin{array}{c}\text { Radicle } \\
\text { length }(\mathrm{cm})\end{array}$ & $\begin{array}{c}\text { Seedling } \\
\text { length }(\mathrm{cm})\end{array}$ & Vigour \\
\hline \multicolumn{3}{|c|}{ Control } & $56.8 \mathrm{C}$ & $0.395 \mathrm{~B}$ & $2.582 \mathrm{~B}$ & $4.185 \mathrm{I}$ & $4.4 \mathrm{CDE}$ & $8.585 \mathrm{~F}$ & $487.8 \mathrm{H}$ \\
\hline \multirow{12}{*}{ 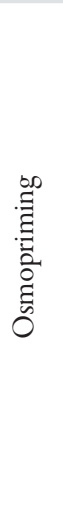 } & \multirow{6}{*}{$12 \mathrm{~h}$} & $-0.6 \mathrm{MPa}$ & $69.65 \mathrm{~A}$ & $0.4061 \mathrm{~B}$ & $2.469 \mathrm{BC}$ & $9.012 \mathrm{BCD}$ & $6.5 \mathrm{~A}$ & $15.51 \mathrm{~A}$ & $1087 \mathrm{~A}$ \\
\hline & & $-0.8 \mathrm{MPa}$ & $66.77 \mathrm{AB}$ & $0.3681 \mathrm{~B}$ & $2.739 \mathrm{~B}$ & 8.448 CDE & $5.36 \mathrm{BC}$ & $13.81 \mathrm{~B}$ & $927 \mathrm{BC}$ \\
\hline & & $-1.0 \mathrm{MPa}$ & $58.15 \mathrm{C}$ & $0.4046 \mathrm{~B}$ & $2.475 \mathrm{BC}$ & $8.273 \mathrm{DE}$ & $5.733 \mathrm{AB}$ & $14.01 \mathrm{~B}$ & $815 \mathrm{CD}$ \\
\hline & & $-1.2 \mathrm{MPa}$ & $56.17 \mathrm{CD}$ & $0.4021 \mathrm{~B}$ & $2.499 \mathrm{BC}$ & $8.212 \mathrm{DEF}$ & $4.677 \mathrm{CD}$ & $12.89 \mathrm{BC}$ & 723.8 DEF \\
\hline & & $-0.6 \mathrm{MPa}$ & $55.57 \mathrm{CD}$ & $0.4046 \mathrm{~B}$ & $2.472 \mathrm{BC}$ & $5.633 \mathrm{H}$ & $4.79 \mathrm{BCD}$ & $10.42 \mathrm{E}$ & $579.5 \mathrm{GH}$ \\
\hline & & $-0.8 \mathrm{MPa}$ & $55.57 \mathrm{CD}$ & $0.2999 \mathrm{C}$ & $3.375 \mathrm{~A}$ & $7.1 \mathrm{FG}$ & $4.887 \mathrm{BCD}$ & $11.99 \mathrm{CD}$ & $666.5 \mathrm{EFG}$ \\
\hline & \multirow[t]{2}{*}{$24 \mathrm{~h}$} & $-1.0 \mathrm{MPa}$ & $57.42 \mathrm{C}$ & $0.3154 \mathrm{C}$ & $3.172 \mathrm{~A}$ & $7.78 \mathrm{EFG}$ & $3.05 \mathrm{~F}$ & $10.83 \mathrm{DE}$ & 621.5 FGH \\
\hline & & $-1.2 \mathrm{MPa}$ & $57.47 \mathrm{C}$ & $0.3178 \mathrm{C}$ & $3.222 \mathrm{~A}$ & 8.548 CDE & 4.552 CDE & $13.1 \mathrm{BC}$ & $749.8 \mathrm{DE}$ \\
\hline & \multirow{4}{*}{$36 \mathrm{~h}$} & $-0.6 \mathrm{MPa}$ & $50.77 \mathrm{D}$ & $0.3947 \mathrm{~B}$ & $2.533 \mathrm{BC}$ & $5.65 \mathrm{H}$ & $5.287 \mathrm{BC}$ & $10.94 \mathrm{DE}$ & $555.5 \mathrm{GH}$ \\
\hline & & $-0.8 \mathrm{MPa}$ & $53.79 \mathrm{CD}$ & $0.3757 \mathrm{~B}$ & $2.685 \mathrm{~B}$ & $6.867 \mathrm{G}$ & $3.025 \mathrm{~F}$ & $9.892 \mathrm{E}$ & $532.3 \mathrm{H}$ \\
\hline & & $-1.0 \mathrm{MPa}$ & $54.44 \mathrm{CD}$ & $0.3961 \mathrm{~B}$ & $2.526 \mathrm{BC}$ & 7.588 EFG & $3.075 \mathrm{~F}$ & $10.66 \mathrm{DE}$ & $580.5 \mathrm{GH}$ \\
\hline & & $-1.2 \mathrm{MPa}$ & $55.72 \mathrm{CD}$ & $0.3756 \mathrm{~B}$ & $2.667 \mathrm{~B}$ & $7.4 \mathrm{EFG}$ & $3.65 \mathrm{EF}$ & $11.05 \mathrm{DE}$ & $619.3 \mathrm{FGH}$ \\
\hline \multirow{4}{*}{ 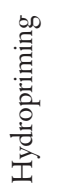 } & & $4 \mathrm{~h}$ & $63.4 \mathrm{~B}$ & $0.5037 \mathrm{~A}$ & $1.994 \mathrm{D}$ & $11.27 \mathrm{~A}$ & $4.4 \mathrm{CDE}$ & $15.67 \mathrm{~A}$ & $993 \mathrm{AB}$ \\
\hline & & $8 \mathrm{~h}$ & $57.3 \mathrm{C}$ & $0.4648 \mathrm{~A}$ & $2.158 \mathrm{CD}$ & $9.532 \mathrm{BC}$ & $4.432 \mathrm{CDE}$ & $13.97 \mathrm{~B}$ & $798.3 \mathrm{D}$ \\
\hline & & $12 \mathrm{~h}$ & $45.1 \mathrm{E}$ & 0.4023 B & $2.492 \mathrm{BC}$ & $9.533 \mathrm{BC}$ & $4.133 \mathrm{DE}$ & $13.67 \mathrm{~B}$ & $615 \mathrm{FGH}$ \\
\hline & & $16 \mathrm{~h}$ & $42.84 \mathrm{E}$ & $0.3899 \mathrm{~B}$ & $2.582 \mathrm{~B}$ & $9.733 \mathrm{~B}$ & $3.133 \mathrm{~F}$ & $12.87 \mathrm{BC}$ & $551.3 \mathrm{GH}$ \\
\hline
\end{tabular}

${ }^{*}$ Figures not sharing the same letters in the same column differ significantly at $\mathrm{p}<0.05$; 1 : Mean germination time 
Tab. 2. Effect of priming treatments on the germination and seedling characteristics of Bromus inermis

\begin{tabular}{|c|c|c|c|c|c|c|c|c|c|}
\hline & \multicolumn{2}{|c|}{ Treatments } & $\begin{array}{c}\text { Final } \\
\text { germination } \\
(\%)\end{array}$ & $\begin{array}{c}\text { Germination } \\
\text { rate }\end{array}$ & $\begin{array}{l}\text { MGT } \\
\text { (day) }\end{array}$ & $\begin{array}{c}\text { Coleoptile } \\
\text { length } \\
(\mathrm{cm})\end{array}$ & $\begin{array}{c}\text { Radicle } \\
\text { length } \\
(\mathrm{cm})\end{array}$ & $\begin{array}{c}\text { Seedling } \\
\text { length } \\
(\mathrm{cm})\end{array}$ & Vigour \\
\hline \multirow{17}{*}{ 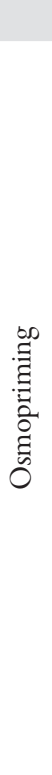 } & \multicolumn{2}{|c|}{ Control } & $61.59 \mathrm{C}$ & $0.2361 \mathrm{D}$ & $4.238 \mathrm{~A}$ & $8.068 \mathrm{FGH}$ & 5.3 ABCDEF & 13.37 DEF & $822.5 \mathrm{FG}$ \\
\hline & \multirow{4}{*}{$12 \mathrm{~h}$} & $-0.6 \mathrm{MPa}$ & $72.29 \mathrm{~B}$ & $0.316 \mathrm{~A}$ & $3.172 \mathrm{D}$ & $10.45 \mathrm{AB}$ & $7.003 \mathrm{~A}$ & $17.45 \mathrm{~A}$ & $1262 \mathrm{ABC}$ \\
\hline & & $-0.8 \mathrm{MPa}$ & $67.12 \mathrm{BC}$ & $0.3002 \mathrm{AB}$ & $3.354 \mathrm{CD}$ & $10.27 \mathrm{ABC}$ & $6.588 \mathrm{AB}$ & $16.86 \mathrm{AB}$ & $1136 \mathrm{BCDE}$ \\
\hline & & $-1.0 \mathrm{MPa}$ & $71.54 \mathrm{~B}$ & $0.295 \mathrm{ABC}$ & $3.392 \mathrm{BCD}$ & $11.01 \mathrm{~A}$ & $6.78 \mathrm{~A}$ & $17.79 \mathrm{~A}$ & $1275 \mathrm{ABC}$ \\
\hline & & $-1.2 \mathrm{MPa}$ & $69.44 \mathrm{~B}$ & $0.287 \mathrm{ABC}$ & $3.492 \mathrm{BCD}$ & $10.21 \mathrm{ABC}$ & $6.533 \mathrm{AB}$ & $16.75 \mathrm{AB}$ & $1165 \mathrm{ABCDE}$ \\
\hline & \multirow{4}{*}{$24 \mathrm{~h}$} & $-0.6 \mathrm{MPa}$ & $41.54 \mathrm{EF}$ & $0.2959 \mathrm{ABC}$ & $3.384 \mathrm{BCD}$ & $7.633 \mathrm{H}$ & $5.968 \mathrm{ABCDE}$ & 13.6 DEF & $563.8 \mathrm{I}$ \\
\hline & & $-0.8 \mathrm{MPa}$ & $41.54 \mathrm{EF}$ & $0.2959 \mathrm{ABC}$ & $3.384 \mathrm{BCD}$ & $9.1 \mathrm{CDEF}$ & $6.44 \mathrm{ABC}$ & $15.54 \mathrm{ABCD}$ & $646 \mathrm{GHI}$ \\
\hline & & $-1.0 \mathrm{MPa}$ & $68.44 \mathrm{BC}$ & $0.2802 \mathrm{ABC}$ & $3.576 \mathrm{BCD}$ & $9.78 \mathrm{BCD}$ & 4.8 CDEFG & 14.58 BCDE & $1005 \mathrm{DEF}$ \\
\hline & & $-1.2 \mathrm{MPa}$ & $67.81 \mathrm{BC}$ & $0.2699 \mathrm{BCD}$ & $3.744 \mathrm{BC}$ & $10.55 \mathrm{AB}$ & $6.802 \mathrm{~A}$ & $17.35 \mathrm{~A}$ & $1177 \mathrm{ABCD}$ \\
\hline & \multirow{4}{*}{$36 \mathrm{~h}$} & $-0.6 \mathrm{MPa}$ & $21.37 \mathrm{G}$ & $0.2599 \mathrm{CD}$ & $3.857 \mathrm{AB}$ & $7.65 \mathrm{H}$ & $4.483 \mathrm{EFG}$ & $12.13 \mathrm{~F}$ & $261 \mathrm{~J}$ \\
\hline & & $-0.8 \mathrm{MPa}$ & $38.32 \mathrm{~F}$ & $0.2808 \mathrm{ABC}$ & $3.593 \mathrm{BCD}$ & 8.868 DEFG & 4.912 BCDEFG & 13.78 CDEF & $530 \mathrm{I}$ \\
\hline & & $-1.0 \mathrm{MPa}$ & $48.52 \mathrm{DE}$ & $0.2823 \mathrm{ABC}$ & $3.576 \mathrm{BCD}$ & $9.587 \mathrm{BCD}$ & $3.608 \mathrm{G}$ & 13.19 DEF & $646.5 \mathrm{GHI}$ \\
\hline & & $-1.2 \mathrm{MPa}$ & $60.99 \mathrm{C}$ & $0.2833 \mathrm{ABC}$ & $3.563 \mathrm{BCD}$ & $9.4 \mathrm{BCDE}$ & $3.928 \mathrm{FG}$ & 13.33 DEF & $817.3 \mathrm{FG}$ \\
\hline & \multirow{4}{*}{$48 \mathrm{~h}$} & $-0.6 \mathrm{MPa}$ & $43.85 \mathrm{EF}$ & $0.2849 \mathrm{ABC}$ & $3.563 \mathrm{BCD}$ & $6.185 \mathrm{I}$ & $3.85 \mathrm{FG}$ & $10.03 \mathrm{G}$ & $439.5 \mathrm{IJ}$ \\
\hline & & $-0.8 \mathrm{MPa}$ & $48.33 \mathrm{DE}$ & $0.2859 \mathrm{ABC}$ & $3.504 \mathrm{BCD}$ & $7.74 \mathrm{GH}$ & 4.707 DEFG & $12.45 \mathrm{EF}$ & $600.5 \mathrm{HI}$ \\
\hline & & $-1.0 \mathrm{MPa}$ & $43.02 \mathrm{EF}$ & $0.2839 \mathrm{ABC}$ & $3.549 \mathrm{BCD}$ & $7.22 \mathrm{HI}$ & 5.313 ABCDEF & $12.53 \mathrm{EF}$ & $542.3 \mathrm{I}$ \\
\hline & & $-1.2 \mathrm{MPa}$ & $53.15 \mathrm{D}$ & $0.294 \mathrm{ABC}$ & $3.408 \mathrm{BCD}$ & 8.387 EFGH & $6.573 \mathrm{AB}$ & $14.96 \mathrm{BCD}$ & $797.5 \mathrm{FGH}$ \\
\hline \multirow{4}{*}{ 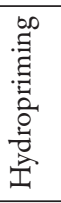 } & & $4 \mathrm{~h}$ & $65.53 \mathrm{BC}$ & $0.239 \mathrm{D}$ & $4.188 \mathrm{~A}$ & $9.717 \mathrm{BCD}$ & 4.932 BCDEFG & $14.65 \mathrm{BCDE}$ & $962 \mathrm{EF}$ \\
\hline & & $8 \mathrm{~h}$ & $82.31 \mathrm{~A}$ & $0.2869 \mathrm{ABC}$ & $3.509 \mathrm{BCD}$ & $9.8 \mathrm{BCD}$ & $6.332 \mathrm{ABCD}$ & $16.13 \mathrm{AB}$ & $1334 \mathrm{AB}$ \\
\hline & & $12 \mathrm{~h}$ & $80.68 \mathrm{~A}$ & $0.2845 \mathrm{ABC}$ & $3.55 \mathrm{BCD}$ & $9.868 \mathrm{ABCD}$ & $6.832 \mathrm{~A}$ & $16.7 \mathrm{AB}$ & $1353 \mathrm{~A}$ \\
\hline & & $16 \mathrm{~h}$ & $67.81 \mathrm{BC}$ & $0.2755 \mathrm{BC}$ & $3.663 \mathrm{BCD}$ & $9.392 \mathrm{BCDE}$ & $6.55 \mathrm{AB}$ & $15.94 \mathrm{ABC}$ & $1082 \mathrm{CDE}$ \\
\hline
\end{tabular}

${ }^{*}$ Figures not sharing the same letters in the same column differ significantly at $\mathrm{p}<0.05$

but it was more clear in hydropiriming for $4 \mathrm{~h}$ and osmopriming (-0.6 Mpa, $12 \mathrm{~h}$ ). Finally, osmoprimed seeds of $B$. tomentellus exhibited higher vigour index than hydro primed seeds. Germination percentage of $B$. inermis was increased due to seed priming, and hydropriming seeds for $8 \mathrm{~h}$ exhibited higher germination percentage than the others (Tab. 2). Germination rate was also affected by seed priming and osmopriming ( $12 \mathrm{~h}$ and $-0.6 \mathrm{Mpa}$ ) exhibited higher speed of germination compared to control and other priming treatments. No significant increse was obtained for radicle length of $B$. inermis due to seed priming. All osmopriming treatments for $12 \mathrm{~h}$ increased coleoptile length significantly but there was no significant difference between all concentrations of PEG in this duration for seed priming. Higher seedling length was observed in osmopriming treatment $(12 \mathrm{~h},-0.6 \mathrm{Mpa})$ compared to other treatments including control. Higher vigour index was observed in hydropriming for $12 \mathrm{~h}$ but this difference was not significant with osmoprime treatment $(12 \mathrm{~h}$, $-0.6 \mathrm{Mpa}$ ) (Tab. 2). B. inermis produced more germinated seeds and vigourous seedlings than $B$. tomentellus but germination rate was higher in B. tomentellus (Fig. 1).

\section{Discussion and conclusions}

Seed germination and seedling growth are critical for seedling at the first life stages and often subject to high mortality rates. The three early phases of germination are: (i) imbibition, (ii) lag phase, and (iii) protrusion of the radical through the testa (Simon, 1984). Priming is a procedure that partially hydrates seed, followed by drying of seed, therefore germination processes begin, but radicle emergence does not occur. There are reports that hydration of seed up to, but not exceeding, the lag phase with priming permits early DNA replication (Bray et al., 1989), increased RNA and protein synthesis (Fu et al., 1988; Ibrahim et al., 1983), greater ATP availability (Mazor et al., 1984), faster embryo growth (Dahal et al., 1990), repair of deteriorated seed parts (Karssen et al., 1989; Saha et al., 1990). These help radicle protrusion through the seed coat and shorten the time to seed germination.

In this research, seed priming increased germination characteristics of under study Bromus geynotyps. This might be due to faster water uptake by primed seed comparing to the control treatment. Similarly, Khan (1993) reported that osmo-conditioning with seed hydration treatments, seed hardening and moisturizing on vermiculite improved the performance of sweet corn seed. The pre- 
a)

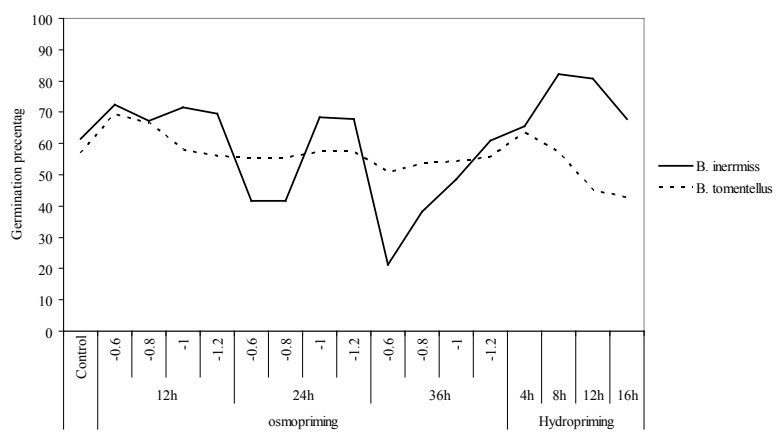

b)

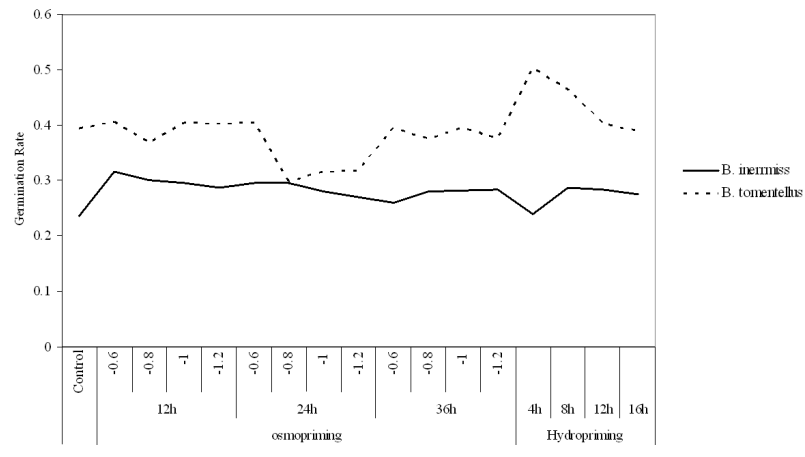

c)

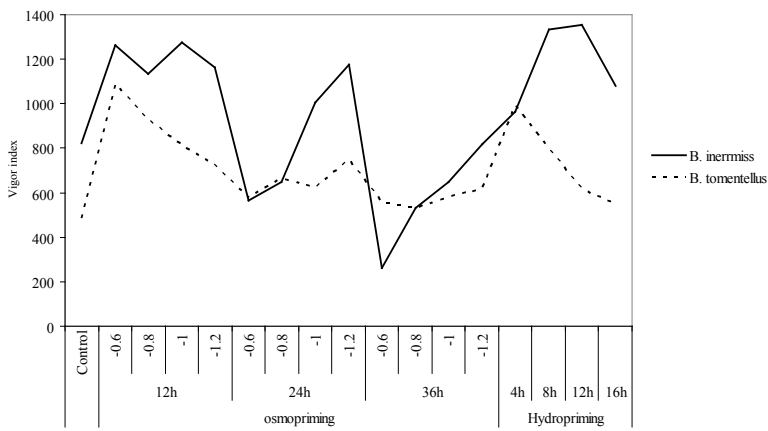

Fig. 1. Germination characteristics of two Bromus species under different priming treatments: $a$ ) Germination percentage; $b$ ) Germination rate; c) Vigour index (seedling length $\times$ germination percentage)

soaking of seeds allows the hydration of membranes and proteins, and the initiation of various metabolic systems. These are arrested when the seeds are dried or moisture is withheld, but recommence when the seeds imbibe water for the second time (Bewley and Black, 1982). Ashraf and Rauf (2001) reported that final germination percentage, fresh and dry weight of corn seed increased by seed priming significantly. So due to all this information and present study it is clear that most effects of seed priming is due to seed hydration. So, optimization of priming technique is very important to achive the best time and concentration combination. Higher and faster germination will increase uniformity and final yield.

According to B. tomentellus and B. inermis values in view point of livestocks forage in Iranian rangelands, also considering their natural habitats soil condition (relatively high moisture and low salinity), findings of this research help us to prepare Bromus seeds through priming tech- niques when their sowing, as high quality forage, is necessary in arid and semi arid areas of Iran. Additionally, it is suggested to work on how could seed priming of Bromus seeds affects tolerance to environmental stress.

\section{Acknowledgments}

The research was supported by Research Vice Chancellor of Natural Resource Faculty, University of Tehran, grant of project No. 7214594/1/1. We would like to thank Dr. H. Arzani for his support. Also we explain our gratitude to Dr. M. R. S. Afkham Olshoara and En. Y. Sasani for their helps during the work.

\section{References}

Association of Official Seed Analysis (AOSA). (1991). Rules for testing seeds. Seed Science and Technology. 12:18-19.

Ashraf, M. and H. Rauf (2001). Inducing salt tolerance in maize (Zea mays L.) through seed priming with chloride salts: Growth and ion transport at early growth stages. Acta Physiologiae Plantarum. 23(4):407-414.

Basra, A. S., M. Farooq, I. Afzal and M. Hussain (2006). Influence of osmopriming on the germination and early seedling growth of coarse and fine rice. International Journal of Agriculture and Biolog. 8:19-21.

Basra, S. M. A., M. Farooq and R. Tabassum (2005). Physiologycal and biochemical aspects of seed vigour enhancement treatments in fine rice (Oryza sativa L.). Seed Science and Technology. 33:623-628.

Bewley, J. D. and M. Black (1982). Physiology and biochemistry of seeds in relations to germination. Vol. 2, Springer-Verlag, Berlin.

Bray, C. M., P. A. Davison, M. Ashraf and R. M. Taylor (1989). Biochemical events during osmopriming of leek seed. Annals of Applied Biology. 102:185-193.

Bruggink, G. T., J. J. Ooms and P. Van der Toorn (1999). Induction of longevity in primed seeds. Seed Science Research. 9:49-53.

Bradford, K. J. (1986). Manipulation of seed water relations wia osmotic priming to improve germination under stress conditions. Horticultural Science. 21:1105-1111.

Chiu, K. Y., C. L. Chen and J. M. Sung (2002). Effect of priming temperature on storability of primed sh-2 sweet corn seed. Crop Science. 42:1996-2003.

Dahal, P., K. J. Bradford and R. A. Jones (1990). Effects of priming and endosperm integrity on seed germination rates of tomato genotypes. II. Germination at reduced water potential. Journal of Experimental Botany. 41:1441-1453.

Dearman, J., P. A. Brocklehust and R. L. K. Drew (1987). Effect of osmotic priming and aging on the germination and emergence of carrot and leek seed. Annual Applied Biology. 111:717-722.

Ellis, R. A. and E. H. Roberts (1981). The quantification of ageing and survival in orthodox seeds. Seed Science and 
108

Technology. 9:373-409.

Farooq, M., S. M. A. Basra, I. Afzal and A. Khaliq (2006). Optimization of hydropriming techniques for rice seed invigouration. Seed Science and Technology. 34:529-534.

Farooq, M., S. M. A. Basra and A. Wahid (2006a). Priming of field-sown rice seed enhances germination, seedling establishment, allometry and yield. Plant Growth Regulation. 49:285-294

Farooq, M., S. M. A. Basra, R. Tabassum and I. Afzal (2006b). Enhancing the performance of direct seeded fine rice by seed priming. Plant Production Science. 9:446-456.

Farooq, M., S. M. A. Basra and M. B. Khan (2007a). Seed priming improves growth of nursery seedlings and yield of transplanted rice. Arch. Agronomy and Soil Science. 53:311-322.

Farooq, M., S. M. A. Basra and N. Ahmad (2007b). Improving the performance of transplanted rice by seed priming. Plant Growth Regulation. 51:129-137.

Fu, J. R., X. H. Lue, R. Z. Chen, B. Z. Zhang, Z. S. Liu, Z. S. $\mathrm{Ki}$ and C. Y. Cai (1988). Osmoconditioning of peanut (Arachis hypogaea L.) seeds with PEG to improve vigour and some biochemical activities. Seed Science and Technology. 16:197-212

Giri, G. S. and W. F. Schilinger (2003). Seed priming winter wheat for germination, emergence and yield. Crop Science. 43:2135-2141.

Heydecker, W. and P. Coolbaer (1977). Seed treatments for improved performance survey and attempted prognosis. Seed Science and Technology. 5:353-425.

Hartz, T. K. and J. Caprile (1995). Germination of sh2 sweet corn following seed disinfestations, solid matrix priming and microbial seed treatment. HortScience. 30:1400-1402.

Heydecker, W. and P. Coolbear (1978). Seed treatment for improved performance: Survey and attempted prognosis. Seed Science and Technology. 5:353-425.

Ibrahim A. E., E. H. Roberts and A. H. Murdoch (1983). Viability of lettuce seed. II. Survival and oxygen uptake in osmotically controlled storage. Journal of Experimental
Botany. 34:631-640.

Janmohammadi, M., P. Moradi Dezfuli and F. Sharifzadeh (2009). Seed invigouration techniques to improve germination and early growth of inbred lines of maize under salinity and drought stress. Genetic Application in Plant Physiology. 34(3-4):215-226.

Karssen, C. M., A. Haigh, P. Van Der Toorn and R. Wages (1989). Physiological mechanism involved in seed priming, p. 269280. In: Recent advances in development and germination of seed. Plenum Press, New York.

Khan, A. A. (1992). Preplant physiological seed conditioning. Horticultural Review. 13:131-181.

Kaur, S., A. K. Gupta and N. Kaur (2005). Seed priming increases crop yield possibly by modulating enzymes of sucrose metabolism in chickpea. Journal of Agronomy and Crop Science. 191:81-87.

Kaya, M. D., G. Okcu, M. Atak, Y. Cikılı and O. Kolsarıcı (2006). Seed treatments to overcome salt and drought stress during germination in sunflower (Helianthus annuus L.). European Journal of Agronomy. 24:291-295.

Mazor, L., M. Perl and M. Negbi (1984). Changes in some ATP dependent activities in seed during treatment with polyethylene glycol and during redrying process. Journal of Experimental Botany. 35:1119-1127.

Murungu, F. S., C. Chiduza, P. Nyamugafata, L. J. Clark, W. R. Whalley and W. E. Finch-Savage (2004). Effects of "on-farm seed priming" on consecutive daily sowing occasions on the emergence and growth of maize in semi-arid Zimbabwe. Field Crops Research. 89:49-57.

Parera, C.A. and D. J. Cantliffe (1994). Pre-sowing seed priming. Horticultural Review. 16:109-141.

Saha, R., A. K. Mandal and R. N. Basu (1990). Physiology of seed invigouration treatments in soybean (Glycine max L.). Seed Science and Technology. 18:269-276.

Styer, R. C. and D. J. Cantliffe (1983). Evidence of repair processes in onion seed during storage at high seed moisture contents. Journal of Experimental Botany. 34:277-282. 